\title{
Effect of Breed and Caponisation on the Growth Performance, Carcass Composition, and Fatty Acid Profile in the Muscles of Greenleg Partridge and Polbar Breeds
}

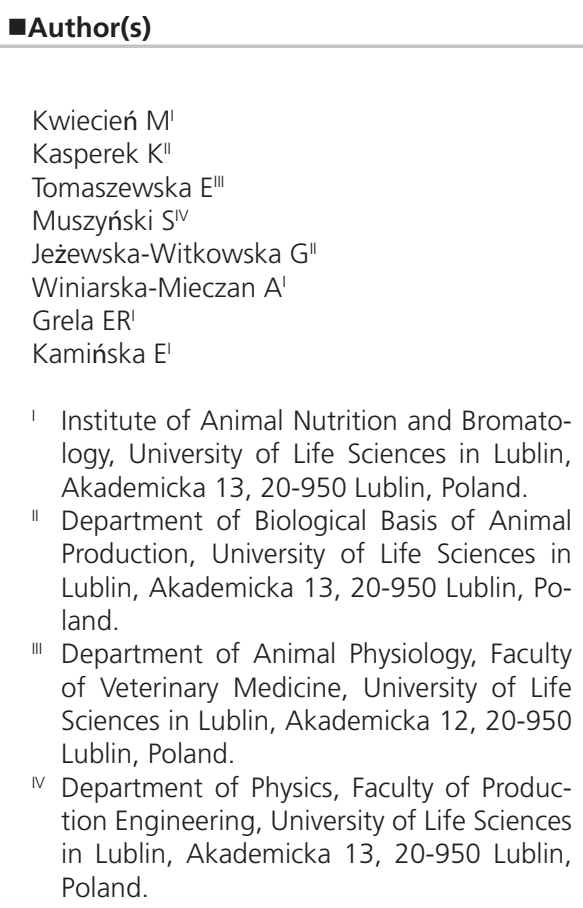

\section{Mail Address}

Corresponding author e-mail address Małgorzata Kwiecień

Institute of Animal Nutrition and Bromatology, University of Life Sciences in Lublin, Akademicka 13, 20-950 Lublin, Poland.

Phone: +48814456936

Email: malgorzata.kwiecien@up.lublin.pl

\section{aKeywords}

Carcass quality, muscle, Polbar, Greenleg Partridge, capon.

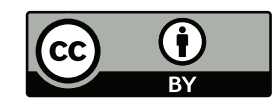

Submitted: 06/February/2018 Approved: 23/April/2018

\section{ABSTRACT}

The aim of the study was to determine the impact of caponisation of Polbar $(\mathrm{Pb})$ and Greenleg Partridge (Zk) breeds on the production performance, carcass composition, and the nutrient content and fatty acid profile in the breast and thigh muscles and abdominal fat. From 18 weeks of age to the end of the experiment, the Zk capons were significantly heavier than the cocks. The Zk capons had higher $(p \leq 0.05)$ weight and share of breast and leg muscles. At 24 weeks of age, we noted an increase in the total content of $n-3$ PUFA and linolenic acid $C_{18: 3}$ in the breast muscles of the Zk and Pb capons. The content of PUFA and $n-3$ PUFA in thigh muscles and the $n 6 / n 3$ ratio were reduced in the $\mathrm{Pb}$ capons at 24 weeks of age, compared with the Zk cocks. Caponisation of the $\mathrm{Pb}$ cocks had a beneficial effect on the final body weight, feed intake, and slaughter characteristics, in comparison with the noncaponised birds of this breed. A tendency towards an increased total share of PUFA and MUFA, a significantly higher content of $n-3$ PUFA, and a lower $(p \leq 0.05) n-6 / n-3$ ratio were found for the breast muscles of the $\mathrm{Pb}$ capons. Both breeds are a good material for production of capons. The meat of the capons of both breeds exhibited a beneficial, higher PUFA/SFA ratio, higher $n-3$ PUFA and MUFA content, and a more favourable $n-6 / n-3$ ratio.

\section{INTRODUCTION}

The increasing intensification of poultry production and breeding excludes the use of native chicken lines due to their poor performance (Połtowicz \& Doktor, 2012). Despite their poor performance, native lines exhibit a number of distinct production, functional, and phenotypic traits, e.g. taste and nutritional values of eggs and meat. These traits have been preserved in pure lines, which have not been selected over many generations due to the implementation of programs of conservation of genetic resources. In Poland, the genetic potential is based on pure lines of Greenleg Partridge, Yellowleg Partridge, Polbar, Sussex, Rhode Island Red, Barred Rock, and New Hampshire breeds. They can be used as a source of meat or material for production of slow-growing broiler chicken hybrids (Sokołowicz et al., 2016). Besides their unique genetic profile, native breeds are a source of unique quantitative and qualitative traits, which cannot be found in high-performance breeds (Krawczyk et al., 2011). Given the consumers' preferences for meat with low fat content and an agreeable flavour and odour (Van Loo et al., 2010; Walley et al., 2015; Sokołowicz et al., 2016), an interesting alternative in poultry production based on native breed flocks is the tradition of caponisation (Calik, 2014; Kwiecień et al., 2015; Franco et al., 2016; Calik et al., 2017). An additional advantage of this procedure is the use of superfluous numbers of cocks among birds that are intended for rearing. In Italy, France, China, and the United States, capons are 
Kwiecień M, Kasperek $\mathrm{K}$, Tomaszewska E, Muszyński S, Jeżewska-Witkowska G, Winiarska-Mieczan A Grela ER, Kamińska E
Effect of Breed and Caponisation on the Growth Performance, Carcass Composition, and Fatty Acid Profile in the Muscles of Greenleg Partridge and Polbar Breeds sold as high-quality products (Sirri et al., 2009). The meat of the native Greenleg Partridge breed contains less fat and cholesterol and is more delicate, juicy, and tender than the meat of non-castrated cocks (Sirri et al., 2009; Calik et al., 2015; Guo et al., 2015).

Removal of cocks' tests results in deficient production of androgens, which is reflected in a smaller size of the comb and wattle, a decreased level of aggressiveness (Chen et al., 2007), and reduced sexual drive (Chen et al., 2006). In turn, the energy retained contributes to increased efficiency of feed conversion into growth (Rikimaru et al., 2009; Volk et al., 2011), fat deposition, and improved quality of meat (Volk et al., 2011; Calik et al., 2015; Kwiecień et al., 2015; Zawadzka et al., 2016).

The use of the native Zk breed for production of capons has been investigated by few researchers (Calik et al. 2015; Kwiecień et al., 2015; Adamski et al., 2016; Zawadzka et al., 2016; Gesek et al., 2017). As indicated in a study conducted by Kwiecień et al. (2015), Zk capons exhibited a beneficial weight gain of the breast muscle, increased content of fat (abdominal, intramuscular), and favourable changes in thigh muscles, i.e. an increase in the total content of MUFA and PUFA as well as PUFA ${ }_{n-6}$. The results reported by Calik et al. (2015) and Zawadzka et al. (2016) demonstrate that Zk capons are characterised by higher body weight, dressing percentage, and share of breast and thigh muscles, stomach, and abdominal fat. Another native breed that can be used for production of capons and, simultaneously, high-quality poultry meat is the Polbar (Pb) breed (Gryzińska et al., 2014). The result of caponisation of $\mathrm{Pb}$ cocks is interesting, since this is a synthetic breed originating from crossing of the Greenleg Partridge breed with cocks of the heavy breed Barred Plymouth Rock (Muszyński et al., 2017).

The objective of the study was to determine the effect of caponisation of the $\mathrm{Pb}$ and $\mathrm{Zk}$ breeds on the production performance, carcass composition, nutrient content, and fatty acid profile in muscles and abdominal fat.

\section{MATERIAL AND METHODS}

\section{Bird management and experimental design}

All procedures applied in the research were approved by the Local Ethics Committee on Animal Experimentation of the University of Life Sciences in Lublin, Poland (No. 33/2013; 16 April 2013). The study material comprised Greenleg Partridge cocks from the
Zk line and Polbar cocks from the Pb line reared at the University of Life Sciences in Lublin. The experiment was conducted on $200 \mathrm{Zk}$ and $200 \mathrm{~Pb}$ cocks, which were individually weighed, labelled, and randomly assigned to the groups. 8-week-old birds weighing over $600 \mathrm{~g}$ underwent the castration procedure carried out by a veterinary doctor and his assistant, as described in detail by Tomaszewska et al. (2016). Afterwards, the cocks were divided into two groups as described above (capons and non-castrated cocks). At 8 weeks, the chickens of each breed were assigned to a control group (50 birds in 10 pens with 5 birds in each) and a caponised experimental group (50 birds in 10 pens with 5 birds in each). The birds were reared to 24 weeks of age in a litter system with controlled temperature and humidity.

Throughout the experimental period, all caponised and non-caponised cocks of both breeds were fed ad libitum with standard complete diets for multi-purpose hens corresponding to the periods of rearing, i.e. from 1 to 8 weeks of age, from 8 to 18 weeks of age, and above 18 weeks of age. The diets were based on corn, wheat, and oat middlings as wellpost-extraction soybean meal and sunflower seeds. The composition and nutritive value of the diets are presented in Table 1.

\section{Sampling and measurements}

Between 6 and 24 weeks of age, the birds were weighed individually every 2 weeks, the collective feed intake was assessed, and the birds' health status was analysed. After the rearing period, i.e. at 24 weeks of age, 10 birds with body weight corresponding to the mean value were selected from each group. Ten hours before the slaughter (Council Regulation (EC) No. 1099/2009; 24 September 2009), the selected birds were given no feed but were provided with unlimited access to water. The birds were slaughtered by decapitation after mechanical stunning. Next, the carcasses were subjected to simplified dissection analysis (Ziołecki \& Doruchowski, 1989) and livers, hearts, stomachs, breast and leg muscles, femora, tibias, andabdominal fat were collected. The individual carcass elements were weighed, which allowed determination of their percentage share in the chilled carcass weight, packed into labelled plastic bags, and frozen (at $-25^{\circ} \mathrm{C}$ ) until analysis.

\section{Feed analyses}

The chemical composition of the breast and thigh muscles sampled from each group was analysed by determination of the content of dry matter, total protein, and crude ash using the AOAC method (2000). 
Kwiecień M, Kasperek $\mathrm{K}$, Tomaszewska E, Muszyński S, Jeżewska-Witkowska G, Winiarska-Mieczan A Grela ER, Kamińska E
Effect of Breed and Caponisation on the Growth Performance, Carcass Composition, and Fatty Acid Profile in the Muscles of Greenleg Partridge and Polbar Breeds
Table 1 - Composition and nutrients content of the diet fed during the trial.

\begin{tabular}{|c|c|c|c|}
\hline \multirow[b]{2}{*}{ Item } & \multicolumn{3}{|c|}{ Complete mixture } \\
\hline & $\begin{array}{c}1-8 \\
\text { week old }\end{array}$ & $\begin{array}{c}\text { 8-18 } \\
\text { week old }\end{array}$ & $\begin{array}{c}>18 \\
\text { week old }\end{array}$ \\
\hline \multicolumn{4}{|l|}{ Ingredients (\%) } \\
\hline Corn & 44.15 & 43.80 & 28.64 \\
\hline Wheat & 20.0 & 20.0 & 20.0 \\
\hline Oat & 5.0 & 10.0 & 20.0 \\
\hline Soybean meal & 20.0 & 10.0 & 10.0 \\
\hline Sunflower meal & 5.0 & 10.0 & 15.0 \\
\hline Soybean oil & 2.40 & 2.50 & 2.00 \\
\hline Monocalcium phosphate & 1.30 & 1.40 & 1.90 \\
\hline Limestone & 0.76 & 0.89 & 1.50 \\
\hline $\mathrm{NaHCO}_{3}$ & 0.12 & 0.14 & 0.16 \\
\hline $\mathrm{NaCl}$ & 0.27 & 0.27 & 0.25 \\
\hline Mineral-vitamins premix & $1.0^{\mathrm{a}}$ & $1.0^{b}$ & $1.0^{b}$ \\
\hline \multicolumn{4}{|l|}{ Calculated nutrient content: } \\
\hline Metabolizable energy (MJ kg-1) & 11.20 & 11.30 & 11.00 \\
\hline Crude protein, \% & 17.32 & 15.24 & 16.72 \\
\hline Crude fat, \% & 4.00 & 4.00 & 3.40 \\
\hline Crude fibre, \% & 5.50 & 6.20 & 7.15 \\
\hline Crude ash, \% & 4.45 & 4.52 & 5.00 \\
\hline $\mathrm{Na}, \%$ & 0.18 & 0.18 & 0.17 \\
\hline $\mathrm{Ca}, \%$ & 1.00 & 1.30 & 4.00 \\
\hline Available $\mathrm{P}, \%$ & 0.35 & 0.32 & 0.40 \\
\hline Lysine, \% & 0.80 & 0.55 & 0.88 \\
\hline Metionine, \% & 0.30 & 0.25 & 0.35 \\
\hline \multicolumn{4}{|c|}{ Fatty acids content (g/100 g of total fatty acids) } \\
\hline $14: 0$ & 0.57 & 0.61 & 0.59 \\
\hline $16: 0$ & 20.2 & 20.8 & 19.9 \\
\hline $18: 0$ & 8.57 & 9.26 & 9.48 \\
\hline $18: 2_{n-6}$ & 23.4 & 22.6 & 23.1 \\
\hline $18: 3_{n-3}$ & 1.28 & 1.30 & 1.29 \\
\hline
\end{tabular}

a1 kg of premix for a period of 1-8 weeks contained: vitamin A (retinol), 3.60 mg; vitamin D3 (cholecalciferol), 0.0625 mg; vitamin E (alpha-tocopherol), 25 mg; vitamin K3 (menadione), $3 \mathrm{mg}$; vitamin B1 (thiamine), $2 \mathrm{mg}$; vitamin B2 (riboflavin), $6 \mathrm{mg}$; vitamin B6 (pyridoxine), 5 mg; vitamin B12 (cyanocobalamin), 0.02 mg; nicotic acid 30 mg; pantothenic acid 15 mg; folic acid 2 mg; biotin 0.2 mg; choline 700 mg; Fe 70 mg; Zn 60 mg; Mn 70 mg; Cu 8 mg; J 1 mg; Se 0.3 mg.

${ }^{b} 1 \mathrm{~kg}$ of premix for a period of nine weeks from the end of the rearing contained: vitamin A (retinol), $3.0 \mathrm{mg}$; vitamin D3 (cholecalciferol), $0.05 \mathrm{mg}$; vitamin E (alpha-tocopherol), 25 mg; vitamin K3 (menadione), 2 mg; vitamin B1 (thiamine), 2 mg; vitamin B2 (riboflavin), 4 mg; vitamin B6 (pyridoxine), 4 mg; vitamin B12 (cyanocobalamin), $0.02 \mathrm{mg}$; nicotic acid $25 \mathrm{mg}$; pantothenic acid $15 \mathrm{mg}$; folic acid $1 \mathrm{mg}$; biotin 0.2 mg; choline 300 mg; Fe 50 mg; Zn 50 mg; Mn 60 mg; Cu 7 mg; J 0.7 mg; Se 0.2 mg.

\section{Qualitative composition of fatty acids muscles and abdominal fat}

The qualitative composition of fatty acids was analysed in ten 24-week-old birds from each group. Gas chromatography was performed in a Varian CP3800 GC-FID apparatus (Varian, Netherlands) using Supelco 37 FAME Mix 47885-U standards (Sigma, UK) to determine the content and identify fatty acids in the feed mixtures, breast and thigh muscles, and abdominal fat after previous extraction of fat with Folch's method in a Velp SER apparatus (Velp, Italy) (Winiarska-Mieczan
\& Kwiecień, 2015). The characteristic of the capillary column were as follows: type CP WAX 52CB, DF 0.25 $\mathrm{mm} \times 60 \mathrm{~mm}$, flow rate of gas (helium) carrier-1.4 ml/ min, column temperature $120^{\circ} \mathrm{C}$ gradually increasing by $2{ }^{\circ} \mathrm{C} / \mathrm{min}$ up to $210{ }^{\circ} \mathrm{C}$, determination time 120 min, detector FID temperature $260{ }^{\circ} \mathrm{C}$, other gaseshydrogen and oxygen. Fatty acids were expressed as a percentage of total fatty acids and grouped into saturated fatty acids (SFA), monounsaturated fatty acids (MUFA), and polyunsaturated fatty acids (PUFA). The atherogenic (Al) and thrombogenic (TI) indices (Ulbricht \& Southgate, 1991) and hypocholesterolemic/ hypercholesterolemic ratio $(\mathrm{h} / \mathrm{H})$ (Fernández et al., 2007) were calculated as follows:

$$
\begin{gathered}
\mathrm{Al}=(\mathrm{C} 12: 0+4 \times C 14: 0+\mathrm{C} 16: 0) /\left[\sum \text { MUFA }+\sum(\mathrm{n}-6)+\right. \\
\left.\quad \sum(\mathrm{n}-3)\right] \\
\mathrm{TI}=(\mathrm{C} 14: 0+\mathrm{C} 16: 0+\mathrm{C} 18: 0) /\left[\left(0.5 \times \sum \text { MUFA }+0.5 \times\right.\right. \\
\left.\left.\sum(\mathrm{n}-6)+3 \times \sum(\mathrm{n}-3)\right)+\left(\sum(\mathrm{n}-3) / \sum(\mathrm{n}-6)\right)\right] \\
\mathrm{h} / \mathrm{H}=(\mathrm{C} 18: 1 \mathrm{n}-9+\mathrm{C} 18: 2 \mathrm{n}-6+\mathrm{C} 20: 4 \mathrm{n}-6+\mathrm{C} 18: 3 \\
\mathrm{n}-3+\mathrm{C} 20: 5 \mathrm{n}-3+\mathrm{C} 22: 5 \mathrm{n}-3+\mathrm{C} 22: 6 \mathrm{n}-3) /(\mathrm{C} 14: 0+ \\
\text { C16:0) }
\end{gathered}
$$

\section{Statistical analysis}

The mean body weight values, weight gain, slaughter characteristics, basic chemical composition of muscles, and fatty acid profiles were analysed with a two-way analysis of variance with interaction (GLM), and the significance of differences between the means in the analysed groups was determined with Tukey's test at $P \leq 0.05$ (Model 1). A two-way analysis of variance was used to assess the effect of the breed and caponisation on the analysed traits. One-way analysis of variance was only used in the case of the assessment of the fatty acid profile in the abdominal fat, where the effect of the breed was examined (Model 2). Statistical SAS software was applied (version 9.4 SAS Institute Inc. Cary, NC). The following models were used:

\section{Model 1}

$$
y_{i j k}=\mu+\alpha_{i}+\beta_{j}+(\alpha \beta)_{i j}+e_{i j k}
$$

where: $y_{i j k}-k^{\text {th }}$ observation from the $i^{\text {th }}$ and $j^{\text {th }}$ groups, $\mu$ - mean value of the trait in the population, $\alpha_{i}$ - effect of the $i^{\text {th }}$ group, $\beta_{j}$ - effect of the $j^{\text {th }}$ group, $e_{i j k}$ - error $=$ effect related to individual variability and measurement error, $(\alpha \beta)_{i j}$ - effect of the interactions between the factors.

\section{Model 2:}

$$
\mathrm{y}_{\mathrm{ijk}}=\mu+\alpha_{\mathrm{i}}+\mathrm{e}_{\mathrm{ijk}}
$$

gdzie: $y_{i j k}-k^{\text {th }}$ observation from the $i^{\text {th }}$ and $j^{\text {th }}$ groups, $\mu$ - mean value of the trait in the population, $\alpha_{i}$ - effect of the $i^{\text {th }}$ group, $e_{i j k}$ - error $=$ effect related to individual variability and measurement error. 
Kwiecień M, Kasperek K, Tomaszewska E, Muszyński S, Jeżewska-Witkowska G, Winiarska-Mieczan A Grela ER, Kamińska E

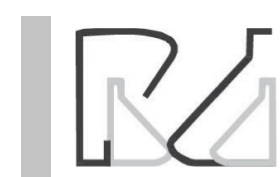

\section{RESULTS}

\section{Growth performance}

The caponisation procedure induced changes in the appearance and behaviour of the capons in both breeds. The capon cocks became less aggressive and quieter, they stopped crowing, and their combs and wattles were light yellow.

No differences in the body weight were found between the capons and non-caponised cocks in the Zk breed before 18 weeks of age (Table 2). At 10 weeks of age, the $\mathrm{Pb}$ capons had lower body weight than the cocks. Between 18 and 24 weeks of age, the Zk capons were significantly heavier than the cocks. In the $\mathrm{Pb}$ group, significantly higher body weight of the capons than that of the cocks was noted at 24 weeks of age.

After caponisation (week 8-10), a lower weight gain was noted in the capon groups (Table 2). In the subsequent rearing periods, there was a reverse tendency in favour of the capons. Between weeks 18-20 and 22-24, significantly higher weight gains
Effect of Breed and Caponisation on the Growth Performance, Carcass Composition, and Fatty Acid Profile in the Muscles of Greenleg Partridge and Polbar Breeds were noted in the capons than in the cocks in both breeds. At weeks 20-22, the Pb and Zk cocks achieved the lowest and the highest weight gains, respectively, and the difference between them reached $410 \%$. The body weight of the Zk cocks declined between week 18 and 20, while the Pb cocks exhibited the lowest weight gain between week 20 and 22, which may have been associated with establishment of a hierarchy in the flocks of the sexually maturing males. The aim of the study was not the observation of birds' behaviour, however during routine controls of all the groups, increased aggression against each other was noted in the groups of roosters, who were fully hormonally active, while no aversive behaviour in capons was observed, irrespective of the breed. During the last 2 weeks prior to the slaughter, the highest weight gain values were noted in the $\mathrm{Pb}$ capons and the lowest in the intact Zk cocks. The mean daily weight gain over the rearing period (weeks 8-24) was higher in the capons of both breeds than in the non-caponised cocks, with significant differences noted only in the Zk group.

Table 2 - Average body weight and weight gains of capons and cocks in respective breeding periods.

\begin{tabular}{|c|c|c|c|c|c|c|c|c|}
\hline \multirow[b]{2}{*}{ Age (weeks) } & \multicolumn{2}{|c|}{$\mathrm{Zk}(\overline{\mathrm{x}})$} & \multicolumn{2}{|c|}{$\mathrm{Pb}(\overline{\mathrm{x}})$} & \multirow[b]{2}{*}{ SEM } & \multicolumn{3}{|c|}{ Influence of } \\
\hline & Capons & Cocks & Capons & Cocks & & Breed & Caponization & $\begin{array}{c}\text { Interaction } \\
\text { breed } \mathrm{x} \text { caponization }\end{array}$ \\
\hline \multicolumn{9}{|c|}{ Body weight (g) } \\
\hline $8^{*}$ & 652.8 & 613.0 & 628.3 & 616.3 & 5.67 & 0.349 & - & - \\
\hline 10 & $861.4^{\mathrm{a}}$ & $884.3^{a}$ & $782.9^{b}$ & $859.9^{a}$ & 8.10 & $<0.001$ & 0.001 & 0.078 \\
\hline 12 & $1122.4^{\mathrm{ab}}$ & $1142.2^{\mathrm{a}}$ & $1049.6^{b}$ & $1108.9^{a b}$ & 9.97 & 0.007 & 0.044 & 0.314 \\
\hline 14 & $1338.0^{\mathrm{ab}}$ & $1359.1^{\mathrm{a}}$ & $1267.1^{\mathrm{b}}$ & $1325.3^{\mathrm{ab}}$ & 10.60 & 0.013 & 0.059 & 0.374 \\
\hline 16 & 1532.8 & 1534.4 & 1461.9 & 1514.5 & 10.88 & 0.038 & 0.214 & 0.241 \\
\hline 18 & 1728.2 & 1689.6 & 1687.1 & 1732.3 & 12.13 & 0.973 & 0.893 & 0.089 \\
\hline 20 & $1856.0^{\mathrm{a}}$ & $1670.3^{b}$ & $1819.0^{a}$ & $1810.8^{a}$ & 14.28 & 0.052 & $<0.001$ & 0.001 \\
\hline 22 & $1915.7^{\mathrm{a}}$ & $1787.2^{b}$ & $1896.3^{a}$ & $1833.6^{\mathrm{ab}}$ & 13.68 & 0.611 & $<0.001$ & 0.217 \\
\hline 24 & $2056.5^{a}$ & $1841.6^{b}$ & $2097.1^{a}$ & $1927.9^{b}$ & 16.35 & 0.026 & $<0.001$ & 0.419 \\
\hline \multicolumn{9}{|c|}{ Weight gain (g) } \\
\hline $8-10$ & $218.2^{b}$ & $271.3^{a}$ & $156.2^{c}$ & $251.6^{a b}$ & 5.57 & $<0.001$ & $<0.001$ & 0.015 \\
\hline $10-12$ & 257.1 & 263.7 & 262.8 & 248.9 & 3.69 & 0.547 & 0.627 & 0.173 \\
\hline $12-14$ & 216.8 & 215.6 & 217.5 & 203.0 & 3.84 & 0.442 & 0.396 & 0.316 \\
\hline $14-16$ & 194.8 & 175.3 & 194.8 & 189.1 & 4.37 & 0.433 & 0.153 & 0.433 \\
\hline $16-18$ & $195.4^{\mathrm{a}}$ & $155.2^{b}$ & $225.2^{\mathrm{a}}$ & $217.9^{a}$ & 5.12 & $<0.001$ & 0.012 & 0.078 \\
\hline $18-20$ & $127.8^{\mathrm{a}}$ & $-19.3^{c}$ & $131.9^{a}$ & $78.4^{b}$ & 7.36 & $<0.001$ & $<0.001$ & $<0.001$ \\
\hline $20-22$ & $63.6^{\mathrm{b}}$ & $116.9^{a}$ & $81.8^{\mathrm{b}}$ & $22.9^{c}$ & 5.60 & $<0.001$ & 0.774 & $<0.001$ \\
\hline $22-24$ & $140.8^{b}$ & $59.6^{c}$ & $200.7^{a}$ & $106.2^{b}$ & 6.89 & $<0.001$ & $<0.001$ & 0.536 \\
\hline \multicolumn{9}{|c|}{ Average daily gain overall } \\
\hline 8 - 24 week & $12.68^{\mathrm{a}} \pm 0.41$ & $11.13^{b} \pm 0.34$ & $13.15^{\mathrm{a}} \pm 0.38$ & $11.82^{\mathrm{ab}} \pm 0.40$ & & 0.133 & $<0.001$ & 0.769 \\
\hline
\end{tabular}

SEM - standard error of the means.

"-weight before caponization.

$a, b, c$ - mean values in rows with different letters differ significantly at $p<0.05$ (Tukey test).

During weeks 12-14, the highest feed intake was observed in the non-caponised $\mathrm{Pb}$ cocks, in comparison with the other groups (Table 3). This was similar between weeks 16 and 18; in turn, between 18 and 20 weeks of rearing, the non-caponised Zk cocks exhibited the lowest feed intake rates. In the last period 
Table 3 - Average daily feed intake ( $\mathrm{g}$ ) per birds of capons and cocks in respective breeding periods.

\begin{tabular}{|c|c|c|c|c|c|c|c|c|}
\hline \multirow[b]{2}{*}{ Age (weeks) } & \multicolumn{2}{|c|}{ Zk $(\bar{x})$} & \multicolumn{2}{|c|}{$\mathrm{Pb}(\overline{\mathrm{x}})$} & \multirow[b]{2}{*}{ SEM } & \multicolumn{3}{|c|}{ Influence of } \\
\hline & Capons & Cocks & Capons & Cocks & & Breed & Caponization & $\begin{array}{c}\text { Interaction } \\
\text { breed } x \text { caponization }\end{array}$ \\
\hline $10-12$ & 84.3 & 86.9 & 82.6 & 91.2 & 3.49 & 0.696 & 0.114 & 0.396 \\
\hline $12-14$ & $92.9^{b}$ & $94.1^{b}$ & $88.6^{b}$ & $111.4^{a}$ & 3.51 & 0.068 & 0.001 & 0.003 \\
\hline $14-16$ & 101.3 & 100.2 & 97.9 & 98.5 & 1.98 & 0.207 & 0.872 & 0.685 \\
\hline $16-18$ & $108.0^{\mathrm{ab}}$ & $94.0^{\mathrm{b}}$ & $104.0^{\mathrm{b}}$ & $120.7^{a}$ & 3.63 & 0.003 & 0.721 & $<0.001$ \\
\hline $18-20$ & $104.4^{\mathrm{a}}$ & $79.5^{b}$ & $104.3^{a}$ & $109.9^{a}$ & 3.68 & $<0.001$ & 0.011 & $<0.001$ \\
\hline $20-22$ & 117.0 & 110.6 & 115.5 & 120.7 & 3.07 & 0.166 & 0.845 & 0.065 \\
\hline $22-24$ & $94.2^{c}$ & $105.2^{\mathrm{bc}}$ & $112.5^{b}$ & $127.7^{a}$ & 3.36 & $<0.001$ & $<0.001$ & 0.535 \\
\hline
\end{tabular}

SEM - standard error of the means.

$a, b, c$ - mean values in rows with different letters differ significantly at $p<0.05$ (Tukey test).

of rearing (week 22-24), the Zk capons consumed significantly lower amounts of feed, i.e. by $19.4 \%$ and $35.6 \%$, than the $\mathrm{Pb}$ capons and cocks, respectively.

\section{Slaughter analysis of carcasses and organ weight}

Significantly higher values of skin with subcutaneous fat were observed in the capons of both breeds than in the non-caponised cocks (Table 4). The slaughter analysis revealed that the capons were heavier than the cocks within the same breed, but the difference was statistically significant only in the Pb breed (Table 4). Caponisation did not have an impact on chilled carcass weight. Consequently, the cocks within the breeds were characterised by a higher dressing percentage than that of the capons, and this correlation was confirmed in the Zk breed. The caponisation surgery contributed to reduction of the weight and share of

Table 4 - Slaughter characteristics of capons and cocks at 24 weeks of age.

\begin{tabular}{|c|c|c|c|c|c|c|c|c|}
\hline \multirow[b]{2}{*}{ Item } & \multicolumn{2}{|c|}{$\mathrm{Zk}(\overline{\mathrm{x}})$} & \multicolumn{2}{|c|}{$\mathrm{Pb}(\overline{\mathrm{x}})$} & \multirow[b]{2}{*}{ SEM } & \multicolumn{3}{|c|}{ Influence of } \\
\hline & Capons & Cocks & Capons & Cocks & & Breed & Caponization & $\begin{array}{c}\text { Interaction } \\
\text { breed } \mathrm{x} \text { caponization }\end{array}$ \\
\hline $\mathrm{BW}(\mathrm{g})$ & $1956^{\mathrm{ab}}$ & $1748^{b}$ & $2062^{a}$ & $1824^{b}$ & 52.68 & 0.092 & $<0.001$ & 0.773 \\
\hline Weight carcasses chilled (g) & 1349.1 & 1266.2 & 1400.5 & 1275.1 & 42.08 & 0.478 & 0.018 & 0.617 \\
\hline Dressing percent (g/100 g BW) & $68.99^{b}$ & $72.43^{a}$ & $67.72^{b}$ & $69.97^{a b}$ & 0.657 & 0.008 & $<0.001$ & 0.367 \\
\hline \multicolumn{9}{|c|}{ Percentage of carcass parts in body weight } \\
\hline Liver & 1.43 & 1.34 & 1.54 & 1.52 & 0.056 & 0.014 & 0.361 & 0.567 \\
\hline Gizzard & 1.54 & 1.42 & 1.61 & 1.67 & 0.085 & 0.076 & 0.721 & 0.289 \\
\hline Heart & $0.37^{b}$ & $0.50^{a}$ & $0.40^{b}$ & $0.56^{a}$ & 0.019 & 0.024 & $<0.001$ & 0.581 \\
\hline Abdominal fat & $3.09^{a}$ & $0.00^{b}$ & $3.96^{a}$ & $0.00^{b}$ & 0.321 & 0.025 & $<0.001$ & 0.709 \\
\hline Breast meat & $17.8^{\mathrm{a}}$ & $15.1^{\mathrm{b}}$ & $16.6^{\mathrm{ab}}$ & $14.7^{b}$ & 0.494 & $<0.001$ & 0.107 & 0.396 \\
\hline Leg meat & $21.8^{b}$ & $23.7^{a}$ & $22.0^{\mathrm{ab}}$ & $23.3^{\mathrm{ab}}$ & 0.455 & 0.764 & 0.001 & 0.477 \\
\hline Leg bones & $5.10^{b}$ & $5.81^{\mathrm{a}}$ & $5.02^{b}$ & $5.44^{\mathrm{ab}}$ & 0.138 & 0.112 & $<0.001$ & 0.313 \\
\hline Total muscles & $39.6^{\mathrm{ab}}$ & $40.3^{a}$ & $37.0^{b}$ & $37.9^{\mathrm{ab}}$ & 0.712 & 0.001 & 0.272 & 0.893 \\
\hline Skin with subcutaneous fat & 15.5 & 15.1 & 15.6 & 15.0 & 0.453 & 0.123 & 0.534 & 0.258 \\
\hline \multicolumn{9}{|l|}{ Weight edible offal (g) } \\
\hline Liver & $27.9^{a}$ & $23.5^{b}$ & $31.5^{\mathrm{a}}$ & $27.6^{a}$ & 0.989 & $<0.001$ & $<0.001$ & 0.802 \\
\hline Gizzard & $30.3^{a b}$ & $24.8^{b}$ & $32.8^{\mathrm{a}}$ & $30.4^{\mathrm{ab}}$ & 1.666 & 0.020 & 0.023 & 0.359 \\
\hline Heart & $7.2^{b}$ & $8.8^{\mathrm{ab}}$ & $8.2^{b}$ & $10.2^{\mathrm{a}}$ & 0.416 & 0.007 & $<0.001$ & 0.634 \\
\hline \multicolumn{9}{|l|}{ Weight parts of the carcass (g) } \\
\hline Skin with subcutaneous fat & $209.2^{\mathrm{a}}$ & $196.9^{b}$ & $218.3^{a}$ & $195.2^{b}$ & 7.246 & 0.055 & 0.004 & 0.425 \\
\hline Abdominal fat & $42.0^{a}$ & $0.0^{b}$ & $56.4^{\mathrm{a}}$ & $0.00^{b}$ & 4.514 & 0.015 & $<0.001$ & 0.525 \\
\hline Breast meat & $240.7^{a}$ & $209.5^{a b}$ & $210.1^{a b}$ & $187.0^{b}$ & 8.902 & 0.005 & 0.004 & 0.652 \\
\hline Thigh meat & 161.8 & 169.0 & 168.4 & 160.2 & 6.144 & 0.859 & 0.936 & 0.218 \\
\hline Drumsticks meat & 132.4 & 131.6 & 138.4 & 136.2 & 4.747 & 0.272 & 0.754 & 0.884 \\
\hline Femur bones & 29.0 & 31.2 & 29.2 & 27.8 & 0.989 & 0.115 & 0.689 & 0.077 \\
\hline Tibia bones & 39.8 & 42.2 & 40.6 & 41.4 & 1.333 & 1.000 & 0.238 & 0.552 \\
\hline Total meat & 534.9 & 510.1 & 516.9 & 483.4 & 17.17 & 0.201 & 0.098 & 0.801 \\
\hline
\end{tabular}

SEM - standard error of the means; Data are means of 20 birds (10 birds from each pen) per treatment.

a, b-mean values in rows with different letters differ significantly at $p<0.05$. 
the heart and to an increase in the weight and share of abdominal fat in the carcasses of both breeds $(p \leq 0.05)$. The lowest weight of the liver and stomach was noted in the Zk cocks. The Zk capons were characterised by a higher $(p \leq 0.05)$ share and weight of breast muscles, while the cocks of this breed exhibited the highest share of leg muscles. A higher share of bones was noted in the non-caponised Zk cocks, i.e. by $13.9 \%$ and $15.7 \%$ in comparison with the capons of both breeds, respectively.

\section{Chemical composition and fatty acid profile in muscles and abdominal fat}

Caponisation had an effect on the chemical composition of breast and thigh muscles in both breeds.
In comparison with the other groups, the lowest dry matter and crude protein contents in breast muscles and crude fat in thigh muscles were determined in the non-caponised Zk cocks (Table 5). A significantly higher level of crude ash (by 5.5\%) was found in the breast muscles of the Zk capons, in comparison with the cocks of this breed. The content of crude fat in the breast muscles of the Zk cocks was by $152.5 \%$ and $165 \%$ lower $(p \leq 0.05)$ than that in the capons of this breed and non-caponised $\mathrm{Pb}$ cocks, respectively. In turn, significantly lower dry matter content was noted in the thigh muscles of the non-caponised Zk cocks than in the capons of this breed and Pb cocks.

At 24 weeks of age, higher contents of PUFA ${ }_{n-3}$ and linolenic acid $C_{18: 3}$ were noted in the breast muscles

Table 5 - Chemical composition (\%) of the breast and thigh muscles of capons and cocks at 24 weeks of age.

\begin{tabular}{|c|c|c|c|c|c|c|c|c|}
\hline \multirow[b]{2}{*}{ Feature } & \multicolumn{2}{|c|}{ Zk $(\bar{x})$} & \multicolumn{2}{|c|}{$\mathrm{Pb}(\overline{\mathrm{x}})$} & \multirow[b]{2}{*}{ SEM } & \multicolumn{3}{|c|}{ Influence of } \\
\hline & Capons & Cocks & Capons & Cocks & & Breed & Caponization & $\begin{array}{c}\text { Interaction } \\
\text { breed x caponization } \\
\text { Rasa x stan }\end{array}$ \\
\hline \multicolumn{9}{|l|}{ Breast muscles } \\
\hline Dry matter & $26.5^{\mathrm{a}}$ & $25.3^{b}$ & $26.8^{a}$ & $26.9^{a}$ & 0.163 & $<0.001$ & 0.001 & $<0.001$ \\
\hline Crude ash & $1.14^{\mathrm{a}}$ & $1.081^{b}$ & $1.096^{\mathrm{ab}}$ & $1.093^{\mathrm{ab}}$ & 0.013 & 0.291 & 0.03 & 0.051 \\
\hline Crude protein & $24.46^{a}$ & $23.69^{b}$ & $24.78^{a}$ & $24.67^{a}$ & 0.114 & $<0.001$ & $<0.001$ & 0.006 \\
\hline $\begin{array}{l}\text { Crude fat } \\
\text { Thigh muscles }\end{array}$ & $1.01^{\mathrm{a}}$ & $0.40^{\mathrm{b}}$ & $0.84^{\mathrm{ab}}$ & $1.06^{\mathrm{a}}$ & 0.114 & 0.039 & 0.097 & $<0.001$ \\
\hline Dry matter & $25.9^{a}$ & $23.6^{b}$ & $25.1^{\mathrm{ab}}$ & $25.8^{a}$ & 0.413 & 0.116 & 0.065 & $<0.001$ \\
\hline Crude ash & 1.042 & 1.035 & 1.054 & 1.038 & 0.012 & 0.524 & 0.33 & 0.701 \\
\hline Crude protein & 21.2 & 21.3 & 21.1 & 21.3 & 0.180 & 0.785 & 0.461 & 0.98 \\
\hline Crude fat & $3.71^{\mathrm{a}}$ & $1.29^{b}$ & $3.01^{\mathrm{a}}$ & $3.76^{a}$ & 0.415 & 0.039 & 0.049 & $<0.001$ \\
\hline
\end{tabular}

SEM - standard error of the means; Data are means of 20 birds ( 10 birds from each pen) per treatment.

$a, b$ mean values in rows with different letters differ significantly at $p<0.05$.

of the $\mathrm{Zk}$ and $\mathrm{Pb}$ capons and a higher $n-6 / n-3$ ratio was calculated for the cocks of both breeds (Table 6). Furthermore, there was an increase in the total content of saturated fatty acids (SFA) in the Pb breed (cocks and capons), in comparison with the Zk breed. A similar tendency was observed for lauric $\left(C_{12: 0}\right)$ and palmitic $\left(C_{16: 0}\right)$ acids. Anapprox. 19\% higher level of pentadecanoic acid $\left(C_{15: 0}\right)$ was found in the Zk capons, in comparison with the $\mathrm{Zk}$ and $\mathrm{Pb}$ cocks. In turn, the content of myristic acid $\left(C_{14: 0}\right)$ in the breast muscles of the $\mathrm{Pb}$ capons was significantly higher, i.e. by $30.1 \%$ and $40.0 \%$, respectively, than that in the muscles of the Zk capons and cocks. This difference between the cocks of both breeds reached $28.6 \%$. Regardless of the caponisation procedure, a higher Al value in the breast muscle was noted in the Pb breed, and a higher $\mathrm{h} / \mathrm{H}$ ratio was obtained for the Zk breed (Table 7 ). There was a statistically significant difference $(21.3 \%)$ in the TI values for the breast muscles between the Zk capons and $\mathrm{Pb}$ cocks.
There was an impact of caponisation $(p \leq 0.05)$ on the total content of monounsaturated fatty acids (MUFA) in the thigh muscles (Table 6). A significant increase in the content of oleic acid $\left(C_{18: 1}\right)$ was observed in the capons of both breeds. The caponisation procedure contributed to a reduced level of polyunsaturated fatty acids PUFA and PUFA as well as a lower $n-6 / n-3$ ratio in the Pb capons, in comparison with the Zk cocks. A significant decrease in the content of eicosadienoic $\left(C_{20: 2}\right)$ and arachidoneic $\left(C_{20: 4}\right)$ acids was observed in the capons of both breeds, in comparison with the level noted in the cock groups. The Al ratio in the Zk cocks was by $29.4 \%$ and $21.9 \%$ lower $(P \leq 0.05)$ than that in the caponised and non-caponised $\mathrm{Pb}$ birds, respectively. In turn, the $\mathrm{h} / \mathrm{H}$ ratio in the Zk cocks was significantly higher than in the other experimental groups (Table 7). Caponisation of the Pb cocks had a significant effect on the total content of saturated fatty acids (SFA), in comparison with the non-caponised Zk birds. 
Table 6 - Fatty acid profile of breast and thigh muscles samples ( $\mathrm{g} / 100 \mathrm{~g}$ of total fatty acids) of capons and cocks at 24 weeks of age.

\begin{tabular}{|c|c|c|c|c|c|c|c|c|}
\hline \multirow[b]{2}{*}{ Item } & \multicolumn{2}{|c|}{ Zk $(\bar{x})$} & \multicolumn{2}{|c|}{$\mathrm{Pb}(\overline{\mathrm{x}})$} & \multirow[b]{2}{*}{ SEM } & \multicolumn{3}{|c|}{ Influence of } \\
\hline & Capons & Cocks & Capons & Cocks & & Breed & Caponization & $\begin{array}{c}\text { Interaction } \\
\text { breed } \mathrm{x} \text { caponization }\end{array}$ \\
\hline
\end{tabular}

Fatty acids \% ether extract

Breast muscles

\begin{tabular}{|c|c|c|c|c|c|c|c|c|}
\hline $12: 0$ & $0.138^{b}$ & $0.091^{c}$ & $0.205^{a}$ & $0.182^{a}$ & 0.009 & $<0.001$ & $<0.001$ & 0.179 \\
\hline $14: 0$ & $0.594^{b c}$ & $0.552^{c}$ & $0.773^{a}$ & $0.710^{\mathrm{ab}}$ & 0.032 & $<0.001$ & 0.115 & 0.748 \\
\hline $15: 0$ & $0.116^{a}$ & $0.094^{b}$ & $0.110^{\mathrm{ab}}$ & $0.094^{b}$ & 0.005 & 0.536 & $<0.001$ & 0.536 \\
\hline $16: 0$ & $20.14^{c}$ & $18.40^{d}$ & $25.06^{a}$ & $22.35^{b}$ & 0.281 & $<0.001$ & $<0.001$ & 0.096 \\
\hline $17: 0$ & 0.240 & 0.235 & 0.209 & 0.214 & 0.010 & 0.017 & 1.000 & 0.635 \\
\hline 18:0 & 9.41 & 10.92 & 9.62 & 10.65 & 0.521 & 0.948 & 0.019 & 0.651 \\
\hline $20: 0$ & 0.161 & 0.131 & 0.129 & 0.135 & 0.014 & 0.339 & 0.412 & 0.221 \\
\hline$\Sigma$ SFA & $30.85^{c}$ & $30.48^{c}$ & $36.19^{a}$ & $34.39^{b}$ & 0.442 & $<0.001$ & 0.019 & 0.113 \\
\hline $14: 1 n-5$ & $0.038^{b}$ & $0.047^{b}$ & $0.087^{a}$ & $0.043^{b}$ & 0.008 & 0.006 & 0.031 & 0.002 \\
\hline $16: 1 n-7$ & 0.287 & 0.268 & 0.281 & 0.262 & 0.009 & 0.546 & 0.061 & 1.000 \\
\hline $17: 1$ & 0.033 & 0.043 & 0.041 & 0.032 & 0.006 & 0.795 & 0.931 & 0.107 \\
\hline $18: 1 n-9$ & 30.20 & 26.79 & 30.50 & 29.37 & 1.184 & 0.231 & 0.063 & 0.343 \\
\hline $20: 1 n-9$ & 0.471 & 0.439 & 0.402 & 0.387 & 0.022 & 0.01 & 0.299 & 0.705 \\
\hline$\Sigma$ MUFA & 32.92 & 29.83 & 33.15 & 32.03 & 1.179 & 0.307 & 0.083 & 0.409 \\
\hline $18: 2 n-6$ & 26.82 & 23.47 & 24.84 & 23.63 & 0.851 & 0.293 & 0.011 & 0.215 \\
\hline $20: 2 n-6$ & 0.263 & 0.267 & 2.10 & 0.253 & 0.939 & 0.338 & 0.333 & 0.331 \\
\hline $20: 4 n-6$ & 2.103 & 2.406 & 1.834 & 2.289 & 0.171 & 0.267 & 0.033 & 0.659 \\
\hline $18: 3 n-3$ & $0.909^{a}$ & $0.634^{b}$ & $0.937^{a}$ & $0.642^{b}$ & 0.062 & 0.773 & $<0.001$ & 0.873 \\
\hline$\sum$ PUFA & 30.13 & 26.80 & 29.74 & 26.85 & 1.442 & 0.907 & 0.038 & 0.883 \\
\hline$\Sigma$ UFA & 63.04 & 56.63 & 62.89 & 58.88 & 1.962 & 0.595 & 0.012 & 0.546 \\
\hline$\sum$ PUFA $_{n-3}$ & $0.909^{a}$ & $0.634^{b}$ & $0.937^{a}$ & $0.642^{b}$ & 0.062 & 0.773 & $<.0001$ & 0.873 \\
\hline $\begin{array}{l}\sum \text { PUFA }_{n-6} \\
\text { Thigh muscles }\end{array}$ & 29.18 & 26.14 & 28.77 & 26.17 & 1.413 & 0.895 & 0.053 & 0.876 \\
\hline $12: 0$ & $0.165^{b}$ & $0.166^{b}$ & $0.209^{a}$ & $0.217^{a}$ & 0.008 & $<0.001$ & 0.599 & 0.683 \\
\hline $14: 0$ & $0.667^{b}$ & $0.550^{\mathrm{b}}$ & $0.885^{a}$ & $0.853^{a}$ & 0.036 & $<0.001$ & 0.046 & 0.247 \\
\hline $15: 0$ & 0.082 & 0.095 & 0.102 & 0.101 & 0.007 & 0.061 & 0.378 & 0.305 \\
\hline $16: 0$ & $22.62^{\mathrm{a}}$ & $18.15^{b}$ & $23.96^{a}$ & $21.67^{a}$ & 0.873 & 0.009 & $<0.001$ & 0.221 \\
\hline $17: 0$ & $0.159^{a b}$ & $0.188^{a}$ & $0.128^{c}$ & $0.144^{\mathrm{ab}}$ & 0.012 & 0.004 & 0.074 & 0.598 \\
\hline $18: 0$ & $8.251^{\mathrm{ab}}$ & $9.899^{a}$ & $8.151^{b}$ & $9.147^{a b}$ & 0.419 & 0.316 & 0.003 & 0.442 \\
\hline $20: 0$ & $0.131^{b c}$ & $0.212^{\mathrm{a}}$ & $0.097^{c}$ & $0.181^{\mathrm{ab}}$ & 0.014 & 0.028 & $<0.001$ & 0.917 \\
\hline$\Sigma$ SFA & $32.25^{\mathrm{ab}}$ & $29.39^{b}$ & $33.69^{a}$ & $32.47^{a b}$ & 1.021 & 0.033 & 0.053 & 0.428 \\
\hline $14: 1 n-5$ & $0.089^{a b}$ & $0.078^{b}$ & $0.111^{a}$ & $0.111^{\mathrm{a}}$ & 0.007 & $<0.001$ & 0.447 & 0.447 \\
\hline $16: 1 n-7$ & $3.14^{b}$ & $2.38^{c}$ & $4.28^{a}$ & $3.57^{b}$ & 0.15 & $<0.001$ & $<0.001$ & 0.856 \\
\hline $17: 1$ & 0.051 & 0.046 & 0.045 & 0.047 & 0.004 & 0.568 & 0.732 & 0.426 \\
\hline $18: 1 n-9$ & $34.31^{\mathrm{a}}$ & $28.87^{b}$ & $34.61^{a}$ & $29.54^{b}$ & 0.861 & 0.58 & $<0.001$ & 0.835 \\
\hline $20: 1 n-9$ & 0.305 & 0.362 & 0.332 & 0.316 & 0.026 & 0.712 & 0.427 & 0.161 \\
\hline$\Sigma$ MUFA & $39.93^{\mathrm{a}}$ & $33.70^{\mathrm{b}}$ & $41.18^{\mathrm{a}}$ & $35.37^{b}$ & 0.894 & 0.112 & $<0.001$ & 0.816 \\
\hline $18: 2 n-6$ & 23.72 & 25.73 & 22.63 & 25.63 & 1.078 & 0.585 & 0.026 & 0.652 \\
\hline $20: 2 n-6$ & $0.064^{b}$ & $0.136^{a}$ & $0.063^{b}$ & $0.132^{\mathrm{a}}$ & 0.011 & 0.814 & $<0.001$ & 0.888 \\
\hline $20: 4 n-6$ & $1.701^{b}$ & $3.398^{\mathrm{a}}$ & $1.703^{b}$ & $2.685^{a}$ & 0.222 & 0.118 & $<0.001$ & 0.116 \\
\hline $18: 3 n-3$ & 0.877 & 0.785 & 0.933 & 0.902 & 0.069 & 0.215 & 0.376 & 0.659 \\
\hline$\sum$ PUFA & $26.40^{\mathrm{ab}}$ & $30.10^{a}$ & $25.36^{b}$ & $29.39^{a b}$ & 1.156 & 0.455 & 0.002 & 0.888 \\
\hline$\Sigma$ UFA & 66.33 & 63.80 & 66.54 & 64.76 & 1.398 & 0.679 & 0.131 & 0.79 \\
\hline$\sum$ PUFA $_{n-3}$ & 0.877 & 0.785 & 0.933 & 0.902 & 0.069 & 0.215 & 0.376 & 0.659 \\
\hline$\sum$ PUFA $_{n-6}$ & $25.48^{\mathrm{ab}}$ & $29.27^{a}$ & $24.40^{\mathrm{b}}$ & $28.45^{\mathrm{ab}}$ & 1.147 & 0.412 & 0.002 & 0.909 \\
\hline
\end{tabular}

SFA - saturated fatty acids; MUFA - monounsaturated fatty acids; PUFA - polyunsaturated fatty acids; UFA - unsaturated fatty acids; SEM - standard error of the means; Data are means of 20 birds (10 birds from each pen) per treatment.

$a, b, c-$ mean values in rows with different letters differ significantly at $p<0.05$. 
Kwiecień M, Kasperek K, Tomaszewska E, Muszyński S, Jeżewska-Witkowska G, Winiarska-Mieczan A Grela ER, Kamińska E
Effect of Breed and Caponisation on the Growth Performance, Carcass Composition, and Fatty Acid Profile in the Muscles of Greenleg Partridge and Polbar Breeds

Table 7 - Fatty acid indices in breast and thigh meat of capons and cocks at 24 weeks of age.

\begin{tabular}{|c|c|c|c|c|c|c|c|c|}
\hline \multirow[b]{2}{*}{ Item } & \multicolumn{2}{|c|}{ Zk $(\bar{x})$} & \multicolumn{2}{|c|}{$\mathrm{Pb}(\overline{\mathrm{x}})$} & \multirow[b]{2}{*}{ SEM } & \multicolumn{3}{|c|}{ Influence of } \\
\hline & Capons & Roosters & Capons & Roosters & & Breed & Caponization & $\begin{array}{c}\text { Interaction } \\
\text { breed } x \text { caponization }\end{array}$ \\
\hline \multicolumn{9}{|l|}{ Breast } \\
\hline$\sum$ PUFA/SFA & $0.978^{a}$ & $0.885^{\mathrm{ab}}$ & $0.825^{a b}$ & $0.783^{b}$ & 0.047 & 0.011 & 0.161 & 0.596 \\
\hline$n-6 / n-3^{1}$ & $34.23^{\mathrm{ab}}$ & $43.31^{a}$ & $31.20^{b}$ & $41.60^{a}$ & 2.471 & 0.344 & $<0.001$ & 0.792 \\
\hline $\mathrm{Al}^{2}$ & $0.360^{b}$ & $0.372^{b}$ & $0.456^{a}$ & $0.432^{\mathrm{a}}$ & 0.013 & $<0.001$ & 0.652 & 0.165 \\
\hline $\mathrm{Tl}^{3}$ & $0.899^{b}$ & $1.028^{\mathrm{ab}}$ & $1.060^{\mathrm{ab}}$ & $1.091^{\mathrm{a}}$ & 0.045 & 0.018 & 0.083 & 0.284 \\
\hline$h / H^{4}$ & $2.893^{a}$ & $2.804^{a}$ & $2.253^{b}$ & $2.429^{b}$ & 0.069 & $<0.001$ & 0.529 & 0.061 \\
\hline \multicolumn{9}{|l|}{ Thigh } \\
\hline$\Sigma$ PUFA/SFA & $0.841^{b}$ & $1.023^{a}$ & $0.756^{b}$ & $0.907^{a b}$ & 0.045 & 0.030 & $<0.001$ & 0.727 \\
\hline$n-6 / n-3^{1}$ & $31.07^{a b}$ & $39.50^{a}$ & $27.16^{b}$ & $33.36^{\mathrm{ab}}$ & 2.964 & 0.099 & 0.018 & 0.708 \\
\hline $\mathrm{Al}^{2}$ & $0.386^{a b}$ & $0.323^{b}$ & $0.418^{a}$ & $0.394^{a}$ & 0.017 & 0.005 & 0.015 & 0.256 \\
\hline $\mathrm{Tl}^{3}$ & 0.898 & 0.846 & 0.929 & 0.920 & 0.036 & 0.154 & 0.401 & 0.546 \\
\hline$h / H^{4}$ & $2.690^{\mathrm{b}}$ & $3.194^{\mathrm{a}}$ & $2.422^{b}$ & $2.623^{b}$ & 0.127 & 0.002 & 0.009 & 0.241 \\
\hline
\end{tabular}

SFA - saturated fatty acids; MUFA - monounsaturated fatty acids; PUFA - polyunsaturated fatty acids; UFA - unsaturated fatty acids; SEM - standard error of the means; Data are means of 20 birds (10 birds from each pen) per treatment.

a, b- mean values in rows with different letters differ significantly at $p<0.05$.

1 - $n-6 / n-3$ is in the PUFA $n-6 / P U F A ~ n-3$ ratio.

${ }^{2}$ - Al - Atherogenic Index.

3 - TI - Thrombogenic Index

${ }^{4}$ - h/H - Hypocholesterolemic/hypercholesterolemic ratio.

However, higher $(P \leq 0.05)$ levels of lauric $\left(C_{12: 0}\right)$ and myristic $\left(C_{14: 0}\right)$ acids were noted in the thigh muscles of the Pb cocks (caponised and non-caponised), in comparison with the Zk groups. In turn, the content of margaric $\left(C_{17: 0}\right)$, stearic $\left(C_{18: 0}\right)$, and arachidic $\left(C_{20: 0}\right)$ acids was significantly lower in the $\mathrm{Pb}$ capons in comparison with the Zk cocks.

Higher $(P \leq 0.05)$ levels of saturated fatty acids, i.e. pentadecanoic $\left(C_{15: 0}\right)$, palmitic $\left(C_{16: 0}\right)$, margaric $\left(C_{17: 0}\right)$, and stearic $\left(\mathrm{C}_{18: 0}\right)$ acids, were noted in the abdominal fat of the $\mathrm{Pb}$ capons, in comparison with that in the Zk capons (Table 8). Compared with the Zk capons, the abdominal fat of the caponised Pb cocks was characterised by a higher level of eicosadienoic and linolenic acids and lower content of oleic acid. The caponised Pb cocks exhibited a significantly higher proportion of SFA in the total content of fatty acids, which was by $11.9 \%$ higher than that in the Zk capons. In turn, the proportion of MUFA and UFA in the total fatty acids in the Zk capons was by $4.8 \%$ and $2.19 \%$ higher, respectively, in comparison with the $\mathrm{Pb}$ capons. The latter birds, compared with the Zk capons, exhibited significantly higher (by ca. 20\%) levels of PUFA ${ }_{n-3}$ by $12.8 \%$ and $13.1 \%$ and higher values of $\mathrm{Al}$ and $\mathrm{TI}$, respectively. In turn, higher $(p \leq 0.05)$ PUFA/SFA and $n-6 / n-3$ ratios and a $10.3 \%$ higher $\mathrm{h} / \mathrm{H}$ ratio were calculated for the abdominal fat of the Zk capons, in comparison with the $\mathrm{Pb}$ caponised cocks.

\section{DISCUSSION}

The results of the present study show that the caponisation surgery had a significant effect on the final body weight of the birds. At week 24 of the experiment, the capons of both breeds exhibited higher body weight, i.e. by $215 \mathrm{~g}$ in Zk and by 169 $\mathrm{g}$ in $\mathrm{Pb}$, in comparison with the weight of the noncaponised cocks. It was found that the lower mobility of the caponised birds resulted in an increase in the body weight, in particular from week 20 of rearing. It should be noted that, immediately after caponisation, the $\mathrm{Pb}$ capons had lower body weight than the $\mathrm{Pb}$ cocks (week 10, 12, 14), which was not observed in the Zk capons. This may have been related to the postoperative stress induced by the caponisation surgery. In the subsequent periods of rearing, the caponised cocks exhibited greater weight gains and reached higher body weight than the non-caponised birds on day 168 . Furthermore, in the period between the caponisation surgery and week 24 , there was a tendency towards higher feed intake in the Zk cocks than in the Zk capons, whereas a reverse trend was noted in the case of the Pb birds.

Many studies have demonstrated ambiguous effects of caponisation on birds' growth, and the results of such investigations are contradictory (Miguel et al., 2008; Shao et al., 2009; Symeon et al., 2010). It can therefore be assumed that the impact of caponisation on body weight depends on many factors, e.g. age at 
Kwiecień M, Kasperek K, Tomaszewska E, Muszyński S, Jeżewska-Witkowska G, Winiarska-Mieczan A Grela ER, Kamińska E
Effect of Breed and Caponisation on the Growth Performance, Carcass Composition, and Fatty Acid Profile in the Muscles of Greenleg Partridge and Polbar Breeds
Table 8 - Fatty acid profile of abdominal fat samples ( $\mathrm{g} / 100 \mathrm{~g}$ of total fatty acids) of capons at 24 weeks of age.

\begin{tabular}{|c|c|c|c|c|}
\hline \multirow{2}{*}{ Item } & \multicolumn{2}{|c|}{ Capons* } & \multirow{2}{*}{ SEM } & \multirow{2}{*}{$p$-value } \\
\hline & Zk $(\bar{x})$ & $\mathrm{Pb}(\overline{\mathrm{x}})$ & & \\
\hline \multicolumn{5}{|c|}{ Fatty acids $\%$ ether extract } \\
\hline $12: 0$ & 0.251 & 0.250 & 0.0056 & 0.884 \\
\hline $14: 0$ & 0.738 & 0.773 & 0.0071 & 0.094 \\
\hline $15: 0$ & $0.087^{b}$ & $0.097^{a}$ & 0.0026 & 0.022 \\
\hline $16: 0$ & $22.0^{\mathrm{b}}$ & $24.1^{\mathrm{a}}$ & 0.1515 & $<0.001$ \\
\hline $17: 0$ & $0.09^{b}$ & $0.13^{a}$ & 0.0039 & $<0.001$ \\
\hline 18:0 & $5.93^{b}$ & $7.26^{\mathrm{a}}$ & 0.1357 & $<0.001$ \\
\hline $20: 0$ & 0.068 & 0.070 & 0.0025 & 0.548 \\
\hline$\sum$ SFA & $29.3^{b}$ & $32.8^{\mathrm{a}}$ & 0.2271 & $<0.001$ \\
\hline $14: 1 n-5$ & 0.13 & 0.15 & 0.0025 & 0.188 \\
\hline $18: 1 n-9$ & $38.4^{\mathrm{a}}$ & $36.6^{b}$ & 0.1357 & 0.001 \\
\hline $20: 1 n-9$ & 0.062 & 0.064 & 0.0025 & 0.641 \\
\hline$\Sigma$ MUFA & $40.3^{a}$ & $38.4^{b}$ & 0.3123 & 0.001 \\
\hline $18: 2_{n-6}$ & 22.6 & 22.9 & 0.2463 & 0.332 \\
\hline $20: 2_{n-6}$ & $0.147^{b}$ & $0.158^{\mathrm{a}}$ & 0.0037 & 0.038 \\
\hline $20: 4_{n-6}$ & 0.106 & 0.110 & 0.0022 & 0.331 \\
\hline $18: 3_{n-3}$ & $0.80^{\mathrm{b}}$ & $0.96^{\mathrm{a}}$ & 0.0085 & $<0.001$ \\
\hline$\Sigma$ PUFA & 23.7 & 24.1 & 0.2409 & 0.127 \\
\hline \multicolumn{5}{|c|}{ Calculated analysis } \\
\hline$\Sigma$ UFA & $63.9^{a}$ & $62.5^{b}$ & 0.47027 & 0.031 \\
\hline$\sum$ PUFA $_{n-3}$ & $0.80^{\mathrm{b}}$ & $0.96^{\mathrm{a}}$ & 0.00849 & $<0.001$ \\
\hline$\sum$ PUFA $_{n-6}$ & 22.9 & 23.2 & 0.24438 & 0.309 \\
\hline$\Sigma$ PUFA/SFA & $0.81^{a}$ & $0.74^{b}$ & 0.00915 & $<0.001$ \\
\hline$n-6 / n-3^{1}$ & $28.6^{a}$ & $24.3^{b}$ & 0.51589 & $<0.001$ \\
\hline $\mathrm{Al}^{2}$ & $0.39^{b}$ & $0.44^{a}$ & 0.00376 & $<0.001$ \\
\hline$T 1^{3}$ & $0.84^{b}$ & $0.95^{\mathrm{a}}$ & 0.00828 & $<0.001$ \\
\hline $\mathrm{h} / \mathrm{H}^{4}$ & $2.72^{\mathrm{a}}$ & $2.44^{b}$ & 0.02705 & $<0.001$ \\
\hline
\end{tabular}

SFA - saturated fatty acids; MUFA - monounsaturated fatty acids; PUFA - polyunsaturated fatty acids; UFA - unsaturated fatty acids; SEM - standard error of the means; $P$ - level of significance; Data are means of 20 birds ( 10 birds from each pen) per treatment.

a,b- mean values in rows with different letters differ significantly at $p<0.05$.

$1-n-6 / n-3$ is in the PUFA $n-6 /$ PUFA $n-3$ ratio.

${ }^{2}-\mathrm{Al}$ - Atherogenic Index.

${ }^{3}-\mathrm{Tl}$ - Thrombogenic Index.

${ }^{4}$-h/H - Hypocholesterolemic/hypercholesterolemic ratio.

*The fatty acid composition is shown only in the capons, as there is no abdominal fat in cock carcass (Table 4).

caponisation, age at slaughter, breed, susceptibility to stress, and interactions between the factors.

In principle, reduced locomotor activity of caponised birds contributes to a higher feed conversion rate, which is associated with greater body weight gains and deposition of abdominal and intramuscular fat, leading to improved quality of meat (Jacob \& Mather, 2000). Lower dressing percentage values were noted in the capons of both breeds in comparison with the Zk cocks. There are divergent results concerning the dressing percentage presented in various studies (Miguel et al., 2008; Symeon et al., 2012; Guo et al.,
2015), which is probably related to the differences between breeds used for caponisation. In the present study, we report an effect of caponisation on the weight gain and share of breast muscles in the Zk capons, which is in agreement with results of previous studies of this breed (Calik et al., 2015; Kwiecien et al., 2015).

Caponised birds have greater weight of internal organs, in particular that of the liver, as indicated in this study, as well as the stomach and intestines (Calik et al. 2015). A reverse tendency was reported by Miguel et al. (2008) and Symeon et al. (2012). The significant difference in the liver weight may result from the fact that this organ is the primary site of de novo synthesis of fatty acids in birds, and liver increment in heavy breeds is caused by enhanced lipogenesis processes (Chen et al., 2007). The caponisation procedure resulted in an increase in the weight and share of abdominal fat, which may have been caused by the reduction of the testosterone level; this led to enhancement of lipogenesis processes and accumulation of fat in the organism (Chen et al., 2005). The level of testosterone is negatively correlated with adiposity (Chen et al., 2006). The increase in the amount of fat tissue and intramuscular fat, which is dependent on the capons' breed and age at slaughter, improves the flavour values of meat (Chen et al., 2006; Sinanoglou et al., 2011; Volk et al., 2011). This is important to consumers, who seek products that are more attractive than the common poultry foods.

The quality and chemical composition of poultry meat produced in an intensive breeding system depends largely on the genotype (Sirri et al., 2010), but also on the locomotor activity, possibility of feeding, and age at slaughter (Bogosavljević-Bošković et al., 2010). An important parameter influencing the quality of meat is the farming system (Meluzzi et al., 2009). As suggested by Bancos (2010), organic production, which can contribute to the improvement of the sensory properties of meat, is a better alternative to intensive farming. The protein content in the breast and thigh muscles of the capons and non-caponised cocks of both breeds was similar to that reported by other authors (Sirri et al., 2011). There were differences in the content of dry matter and total protein in the breast muscles, i.e. the capons of both breeds were characterised by a higher percentage content of these nutrients than the Zk cocks but did not differ in the levels of these components from the Pb cocks. A similar tendency was observed for the crude fat content in the thigh muscles, whereas higher amounts of this 
Kwiecień M, Kasperek $\mathrm{K}$, Tomaszewska E, Muszyński S, Jeżewska-Witkowska G, Winiarska-Mieczan A Grela ER, Kamińska E

\section{Effect of Breed and Caponisation on the Growth Performance, Carcass Composition, and Fatty Acid Profile in the Muscles of Greenleg Partridge and Polbar Breeds}

component were found in the breast muscles of the Zk capons and $\mathrm{Pb}$ cocks, in comparison with the Zk cocks. Previous studies (Kwiecień et al., 2015) demonstrated significantly higher fat contents in Zk capons than in cocks of this breed. Similarly, Sirri et al. (2009) showed lower levels on adiposity of breast muscles in cocks, compared with capons. Volk et al. (2011) reported greater amounts of abdominal fat in layertype Slovenian hybrid Prelux-G cockerels caponised at 52 days of age and slaughtered on day 185. Studies conducted by Chen et al. (2007) and Calik et al. (2015) demonstrated a tendency towards higher fat content especially in leg muscles (Calik et al., 2015).

Great importance in fat deposition is attributed to birds' age and hormonal status; greater amounts of fat are found in the muscles of hens and caponised cocks (Sirri et al., 2009). The share of intramuscular fat can also increase with age. Breast muscles of 9-week-old chickens were found to have relatively low levels of adiposity (Marcinkowska-Lesiak et al., 2013), whereas a considerably higher share of fat was detected in birds slaughtered at a later age (Eleroğlu et al., 2013). The higher muscle fat content improves the sensory parameters, i.e. meat flavour, juiciness, and tenderness (Miguel et al., 2008), which makes the meat more attractive to consumers and connoisseurs.

The fatty acid composition of meat depends on the composition of the diet and exerts an impact on the meat sensory properties and, indirectly, on human health. Furthermore, the fatty acid composition is also influenced by the breed and age at caponisation (Miguel et al., 2008; Sirri et al., 2009). The difference in the fatty acid composition between breeds may be related to the different fat content in muscles (Kwiecien et al., 2015). The meat of slow-growing chickens is nutritionally healthier, as it contains lower amounts of fat and has higher n-3 PUFA content (Sirri et al., 2011); therefore, it can be preferred by consumers seeking healthy, organic products. During production of Greenleg Partridge and Rhode Island Red chickens, an increase in PUFA (both $n-3$ and $n-6$ ) has been observed (Puchała et al., 2015).

The present investigations indicate that linolenic acid was the major acid in the breast muscles of the capons although there were no statistical differences. This acid generally predominates in the meat of birds fed diets supplemented with sunflower oil (Crespo \& Esteve-Garcia, 2001). Higher SFA content was detected in the $\mathrm{Pb}$ capons. Additionally, it was significantly higher in the breast muscles of the Zk capons than in the $\mathrm{Pb}$ cocks and lower in the thigh muscles of the capons of both breeds than in the Zk cocks. The greatest quantities of $C_{18: 2}, C_{18: 1}, C_{16: 0}, C_{18: 0}$, and $C_{20: 4}$ acids were shown to be present in both

the breast and thigh muscles. In the thigh muscles, significantly higher content of $C_{18: 1}$ was detected in the capons of both breeds, whereas a reverse tendency was noted in the case of $C_{20: 4}$. The present study showed higher levels of MUFA in the Zk and Pb capons, which is advantageous for human health, as these acids improve resistance of the plasma LDL fractions to any changes caused by oxidation and reduce their atherogenic effects (Kris-Etherton et al., 1988). In both muscles of the $\mathrm{Pb}$ capons, there was a lower $n-6 / n-3$ ratio, which is more favourable for health (Simopoulos, 2009). In turn, lower levels of $C_{20: 4}$ synthesised from linoleic acid were detected in the abdominal fat of the capons, compared with its content in the intramuscular fat. This indicates that the capons and intact males probably synthesized arachidonic acid and deposited a lower percentage thereof in the lipid-rich tissues (abdominal fat) than in the meat. This difference was attributed to the inhibition of $\Delta^{6}$-desaturase by caponisation.

Meat is the primary source of fat, in particular dietary SFAs, which plays an important role in lifestyle diseases, e.g. cancer, and cardiovascular diseases (Simopoulos, 2009). The recommended PUFA to SFA ratio is $0.45-0.65$. There are continuous attempts to develop methods for the production of "healthy" meat, i.e. characterised by a higher PUFA:SFA ratio and a beneficial balance between $n-6$ and n-3 PUFA (Wood et al., 2004). In the present study, the PUFA SFA ratio was higher than the value reported by Wood et al. (2004).

The calculated $\mathrm{Al}$ and $\mathrm{Tl}$ indicate the extent to which components of the human diet containing fatty acids can contribute to an increased incidence of coronary heart disease and atherosclerosis (Turan et al., 2007). The lower the value, the lower the probability of development of atherosclerosis and formation of blood clots (Donovan et al., 2000). In the present study, significantly higher Al values were observed in the fat from the breast and thigh muscles in the $\mathrm{Pb}$ breed (capons and non-caponised cocks). In turn, the TI value in the fat from the breast muscles was significantly lower in the Zk capons than in the Pb cocks. Sex hormones have an effect on the $\Delta^{6}$-desaturase activity; these processes are highly complicated and necessitate further research to elucidate the interactions between sex hormones, breeds, and nutrition. 
Kwiecień M, Kasperek K, Tomaszewska E, Muszyński S, Jeżewska-Witkowska G, Winiarska-Mieczan A Grela ER, Kamińska E

\section{CONCLUSIONS}

The present study indicates that caponisation of the $\mathrm{Pb}$ cocks has a beneficial effect on the final body weight, feed intake, and slaughter characteristics. Moreover, in the breast muscles of the $\mathrm{Pb}$ capons, there was a tendency towards a higher total share of PUFA and MUFA as well as significantly higher contents of $n$-3PUFA and a lower $(p \leq 0.05) n-6 / n-3$ ratio, which is advantageous from the consumer's point of view.

Based on the results of production performance, slaughter analysis, and chemical composition of the muscles, it can be concluded that the two breeds are a good material for production of capons. From the nutritional point of view, the meat of both breeds of the capons has a beneficial PUFA/SFA ratio, which is higher than the recommended value, high $n$-3 PUFA and MUFA content, and an advantageous $n-6 / n-3$ ratio. Consumption of Zk capon meat seems to ensure a number of pro-health benefits due to the lower values of the atherogenic and thrombogenic indices and the higher $\mathrm{h} / \mathrm{H}$ ratio in breast muscles, in comparison with the $\mathrm{Pb}$ capons. Nevertheless, these results should be corroborated in further research, which may offer new perspectives for production of birds with a fatty acid composition in meat that is favourable for consumers.

\section{CONFLICT OF INTEREST}

There are no known conflicts. Financial support for this work does no influence its outcome.

The manuscript has been read and approved by all named authors and that there are no other persons who satisfied the criteria for authorship but are not listed. The order of authors listed in the manuscript has been approved by all authors.

\section{REFERENCES}

Adamski M, Kuźnicka,J, Banaszak M,Wegner M. The analysis of meat of Sussex cockerels and capons (S11) at different ages. Poultry Science 2016;95:125-152.

AOAC. Official methods of analysis. $17^{\text {th }}$ ed. Gaithersburg: AOAC International; 2000.

Bancos C. Research on some hygienic factors influence on broiler health, productivity and meat quality [thesis]. Cluj-Napoca (ROM): University of Agricultural Sciences and Veterinary Medicine Cluj-Napoca; 2010.

Bogosavljević-Bošković S, Mitrović S, Djoković R, Dosković V, Djermanović $V$. Chemical composition of chicken meat produced in extensive indoor and free-range systems. African Journal of Biotechnology 2010;9:9069-9075.

Calik J, Krawczyk J, Świątkiewicz S, Gąsior R, Wojtycza K, Połtowicz K, et al. Comparison of the physicochemical and sensory characteristics
Effect of Breed and Caponisation on the Growth Performance, Carcass Composition, and Fatty Acid Profile in the Muscles of Greenleg Partridge and Polbar Breeds

of Rhode Island Red (R-11) capons and cockerels. Annals of Animal Science 2017;17(3):903-917.

Calik J. Capon production - breeding stock, rooster castration, rearing methods, and meat quality. Annals of Animal Science 2014;14:769777.

Calik J, Połtowicz K, Świątkiewicz S, Krawczyk J, Nowak J. Effect of caponization on meat quality of Greenleg Partridge cockerels. Annals of Animal Science 2015;15:541-553.

Chen $\mathrm{KL}$, Chen $\mathrm{TT}$, Lin KJ, Chiou PWS. The effect of caponization age on muscle characteristics in male chicken. Asian-Australasian Journal of Animal Sciences 2007;20:1684-1688.

Chen KL, Chi WT, Chiou PWS. Caponization and testosterone implantation effects on blood lipid and lipoprotein profile in male chickens. Poultry Science 2005;84:547-552.

Chen KL, Hsieh TY, Chiou PWS. Caponization effects on growth performance and lipid metabolism in Taiwan country chicken cockerels. Asian-Australasian Journal of Animal Sciences 2006;19:438-443.

Council Regulation. (EC) No 1099/2009 of 24 September 2009 on the protection of animals at slaughter. Eur-Lex; 2009. Available from: https:// eur-lex.europa.eu/legal-content/EN/ALL/?uri=CELEX\%3A32009R1099

Crespo N, Esteve-Garcia E. Dietary fatty acid profile modifies abdominal fat deposition in broiler chickens. Poultry Science 2001;80:71-78.

Donovan DC, Schingoethe DJ, Baer RJ, Ryali J, Hippen AR, Franklin ST. Influence of dietary fish oil on conjugated linoleic acid and other fatty acids in milk fat from lactating dairy cows. Journal of Dairy Science 2000;83:2620-2628.

Eleroğlu H, Yıldırım A, Işıkı ND, Şekeroğlu A, Duman M. Comparison of meat quality and fatty acid profile in slow-growing chicken genotypes fed diets supplemented with Origanum vulgare or Melissa officinalis leaves under the organic system. Italian Journal of Animal Science 2013;12:395-403.

Fernández M, Ordóñez JA, Cambero I, Santos C, Pin C, De la Hoz L. Fatty acid compositions of selected varieties of Spanish dry ham related to their nutritional implications. Food Chemistry 2007:9:107-112.

Franco D, Pateiro M, Rois D, Vázquez JA, Lorenzo JM. Effects of caponization on growth performance, carcass and meat quality of Mos breed capons reared in free-range production system. Annals of Animal Science 2016;16(3):909-929

Gesek M, Zawacka M, Murawska D. Effects of caponization and age on the histology, lipid localization, and fiber diameter in muscles from Greenleg Partridge cockerels. Poultry Science 2017;96(6):1759-1766.

Gryzińska M, Batkowska J, Andraszek K, Horecka B, Jeżewska-Witkowska G. Changes in plumage color and patterns in Polbar breed chicks (Polish conservative breed) during their first weeks after hatching. European Poultry Science 2014;78.

Guo X, Nan H, Shi D, Zhou J, Wan Y, Zhou B, et al. Effects of caponization on growth, carcass, and meat characteristics and the mRNA expression of genes related to lipid metabolism in roosters of a Chinese indigenous breed. Czech Journal of Animal Science 2015;60:327-333.

Jacob J, Mather FB. Capons [factsheet PS-54]. Gainesville: University of Florida; 2000. Available from: http://ag.udel.edu/poultry/bm/part1old/ Capon.pdf.

Krawczyk J, Sokołowicz Z, Szymczyk B. Effect of housing system on cholesterol, vitamin and fatty acid content of yolk and physical characteristics of eggs from Polish native hens. Archiv für Geflügelkunde 2011;75:151-157. 
Kwiecień M, Kasperek K,

Tomaszewska E, Muszyński S,

Jeżewska-Witkowska G,

Winiarska-Mieczan A

Grela ER, Kamińska E

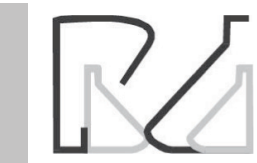

Effect of Breed and Caponisation on the Growth

Performance, Carcass Composition, and Fatty Acid Profile in the Muscles of Greenleg Partridge and

Polbar Breeds
Kris-Etherton PM, Krummel D, Russell ME, Dreon D, Mackey S, Borchers J, et al. The effect of diet on plasma lipids, lipoproteins, and coronary heart disease, Journal of the American Dietetic Association 1988;88:13731400

Kwiecień M, Winiarska-Mieczan A, Zawiślak K, Sroka S. Effect of copper glycinate chelate on biomechanical, morphometric and chemical properties of chicken femur. Annales of Animal Science 2014;14:127139.

Kwiecień M, Kasperek K, Grela E, Jeżewska-Witkowska G. Effect of caponisation on the production performance, slaughter yield and fatty acid profile of muscles of Greenleg Partridge cocks. Journal of Food Science and Technology 2015;52:7227-7235.

Marcinkowska-Lesiak M, Moczkowska M, Wyrwisz J, Stelmasiak A Zdanowska-Sąsiadek Ż, Damaziak K, et al. Effect of sex on meat quality of hybrids breast muscles (CCGP). Zeszyty Problemowe Postępów Nauk Rolniczych 2013;574:39-47.

Meluzzi A, Sirri F, Castelini C, Roncarati A, Melloti P, Franchini A. Influence of genotype and feeding on chemical composition of organic chicken meat. Italian Journal of Animal Science 2009:8:766-768.

Miguel JA, Ciria J, Asenjo B, Calvo JL. Effect of caponization on growth and on carcass and meat characteristics in Castellana Negra native Spanish chickens. Animal 2008;2:305-311.

Muszyński S, Kwiecień M, Tomaszewska E, Świetlicka I, Dobrowolski P, Kasperek $\mathrm{K}$, et al. Effect of caponization on performance and quality characteristic of long bones of Polbar chicken. Poultry Science, 2017;96:491-500.

Połtowicz K, Doktor J. Effect of slaughter age on performance and meat quality of slow-growing broiler chickens. Annals of Animal Science 2012;12:621-631.

Puchała M, Krawczyk J, Sokołowicz Z, Utnik-Banaś K. Effect of breed and production system on physicochemical characteristics of meat from multi-purpose hens. Annals of Animal Science 2015;15:247-261.

Rikimaru K, Yasuda M, Komastu M, Ishizuka J. Effects of caponization on growth performance and carcass traits in Hinai-jidori Chickens. The Journal of Poultry Science 2009;46:351-355.

Shao J, Wu C, Li J, Zhao C. The effects of caponization age on growth performance and blood parameters in male Tibetan chicken. Asian Journal of Animal and Veterinary Advances 2009;4:228-236.

Simopoulos AP. The importance of the omega-6/omega-3 fatty acid balance in health and disease: evolutionary aspect of diet. World Review of Nutrition and Dietetics 2009:102:10-21

Sinanoglou VJ, Mantis F, Miniadis-Meimaroglou S, Symeon GK, Bizelis IA. Effects of caponisation on lipid and fatty acid composition of intramuscular and abdominal fat of medium-growth broilers. British Poultry Science 2011;52:10-317

Sirri F, Bianchi M, Petracci M, Meluzzi, A. Influence of partial and complete caponization on chicken meat quality. Poultry Science 2009;88:14661473
Sirri F, Castelini C, Bianchi M, Petracci M, Meluzzi A, Franchini A. Effect of fast-, medium-, and slow-growing strains of meat quality of chickens reared under the organic farming method. Animal 2010;5:312-319.

Sirri F, Castellini C, Bianchi M, Petracci M, Meluzzi A, Franchini A. Effect of fast, medium and slow growing strains on meat quality of chickens reared under the organic farming method. Animal 2011;5:312-319.

Sokołowicz Z, Krawczyk J, Świątkiewicz S. Quality of poultry meat from native chicken breeds - a review. Annals of Animal Science 2016;16:347-368.

Symeon GK, Mantis F, Bizelis I, Kominakis A, Rogdakis E. Effects of caponization on growth performance, carcass composition, and meat quality of medium growth broilers. Poultry Science 2010;89:14811489.

Symeon GK, Mantis F, Bizelis I, Kominakis A, Rogdakis E. Effects of caponization on growth performance, carcass composition and meat quality of males of a layer line. Animal 2012;6:2023-2030.

Tomaszewska E, Kwiecień M, Muszyński S, Dobrowolski P, Kasperek K, Blicharski T, et al. Long-bone properties and development are affected by caponisation and breed in Polish fowls. British Poultry Science 2016;19(1):159-170.

Turan H, Sönmez G, Kaya Y. Fatty acid profile and proximate composition of the thorn - back ray (Raja clavata $L$. 1758) from the Sinop coast in the Black Sea. Journal of Fisheries Sciences 2007;1:97-103.

Ulbricht TL, Southgate DAT. Coronary heart disease: seven dietary factors. Lancet 1991;338:985-992.

Van Loo E, Caputo V, Nayga RM, Meullenet Jr, Crandall PG, Ricke SC. Effect of organic poultry purchase frequency on consumer attitudes toward organic poultry meat. Journal of Food Science 2010;75:384-397.

Volk M, Malenšek J, Prevolnik M, Škrlep M, Šegula B, Čandek-Potokar M, et al. Differences in carcass and meat quality between organically reared cocks and capons. Agriculture Conspectus Scientificus 2011;76:153156.

Walley K, Parrot P, Custance P, Meledo-Abrahim P, Bourdin A. A review of French consumers purchasing patterns, perceptions and decision factors for poultry meat. World's Poultry Science Journal 2015;71:5-14.

Winiarska-Mieczan A, Kwiecień M. The effects of copperglycine complexes on chemical composition and sensory attributes of raw, cooked and grilled chicken meat. Journal of Food Science and Technology 2015;52(7):4226-4235.

Wood JD, Richardson RI, Nute GR, Fisher AV, Campo MM, Kasapidou E, et al. Effects of fatty acids on meat quality: a review. Meat Science 2004;66:21-32.

Zawacka M, Murawska D, Gesek M. The effect of age and castration on the growth rate, blood lipid profile, liver histology and feed conversion in Green-legged Partridge cockerels and capons. Animal 2017;11(6):1017-1026.

Ziołecki J, Doruchowski W. Evaluation method of poultry slaughter value. Poznań: Wydaw; 1989 